\title{
Rozdział 6 \\ Polityka Unii Europejskiej wobec Stowarzyszenia Narodów \\ Azji Południowo-Wschodniej
}

(Angelika Korczyńska) 



\section{Angelika Korczyńska}

Niniejszy rozdział dotyczy polityki Unii Europejskiej wobec Stowarzyszenia Narodów Azji Południowo-Wschodniej. Organizacja ta jest obecnie przedmiotem zainteresowania wielu państw i podmiotów na arenie międzynarodowej ze względu na potencjał gospodarczy i polityczny, ale również ze względu na proces formowania się nowej siły politycznej w regionie Azji Południowo-Wschodniej. Unia Europejska pogłębia swoje zaangażowanie na tym terytorium przede wszystkim $z$ uwagi na powiązania historyczne, polityczne, gospodarcze oraz kulturowe. Niebagatelną rolę odgrywa tu również dynamiczny wzrost znaczenia politycznego i rozwój gospodarczy organizacji ASEAN.

Stowarzyszenie Narodów Azji Południowo-Wschodniej jest organizacją polityczno-gospodarczą, która rozpoczęła działalność 8 sierpnia 1967 r., na mocy deklaracji z Bangkoku, podpisanej przez pięć państw założycielskich: Indonezję, Malezję, Filipiny, Singapur i Tajlandię. W późniejszym okresie do organizacji dołączyły również: Brunei, Wietnam, Laos, Mjanma i Kambodża, tworząc obecny skład ASEAN. We wspomnianej deklaracji założycielskiej państwa członkowskie wyznaczyły fundamentalne cele organizacji, skupiające się przede wszystkim na przyspieszeniu wzrostu gospodarczego, postępu społecznego i rozwoju kulturowego, promowaniu pokoju i stabilności w regionie oraz zacieśnianiu ogólnej współpracy między partnerami. Wszystkie te czynniki doprowadziły do powstania dobrze prosperującej i rozwijającej się organizacji zrzeszającej kraje regionu, która odgrywa coraz istotniejszą rolę na arenie międzynarodowej ${ }^{1}$.

1 M. Grabowski, Rywalizacja czy integracja? Procesy i organizacje integracyjne w regionie Azji i Pacyfiku na przełomie XX i XXI wieku, Kraków 2015, s. 197-200; Ł. Fijałkowski, A. Polus, Azja Południowo-Wschodnia i Australazja w stosunkach międzynarodowych, Wrocław 2006, s. 31-38. 
Oficjalne stosunki dyplomatyczne pomiędzy Unią Europejską a Stowarzyszeniem Narodów Azji Południowo-Wschodniej zostały nawiązane w 1977 r., ale dynamiki nabrały dopiero w latach 90. XX w. Mimo że na przestrzeni lat stosunki polityczne UE - ASEAN bardzo się rozwinęły, wciąż obserwujemy nacisk na współpracę gospodarczą. Co więcej, możemy zauważyć, że Unia Europejska postrzega ASEAN jako jeszcze nie do końca równego partnera, potrzebującego wciąż pomocy. Powodem takiej sytuacji może być fakt, że ASEAN jest wciąż organizacją rozwijającą się, a jej państwa członkowskie są na bardzo różnych poziomach rozwoju gospodarczego i społecznego, przez co część z nich nadal objęta jest systemem preferencji i otrzymuje pomoc rozwojową od UE. Dodatkowo w regionie występuje również problem łamania praw człowieka.

Celem niniejszego rozdziału jest prześledzenie stosunków UE z ASEAN w czterech głównych obszarach, obejmujących: przesłanki i uwarunkowania współpracy, stosunki polityczne, stosunki gospodarcze oraz pomoc rozwojową, a także przedstawienie głównych problemów w stosunkach obu podmiotów.

Rozdział został podzielony na cztery podrozdziały. W pierwszym przedstawiono początki współpracy i podstawy wzajemnych relacji obu ugrupowań regionalnych w formie krótkiego rysu historycznego. Drugi podrozdział poświęcony jest relacjom politycznym pomiędzy Unią Europejską a Stowarzyszeniem Narodów Azji Południowo-Wschodniej, ze szczególnym naciskiem na proces rozwoju obustronnych relacji, aż po aktualny obraz stosunków politycznych pomiędzy obiema stronami. Trzecia część obejmuje opis obecnych stosunków gospodarczych oraz ich pozytywnych i negatywnych aspektów. Ostatni podrozdział przybliża politykę rozwojową prowadzoną przez UE w regionie Azji Południowo-Wschodniej.

Liczę, że niniejszy rozdział przybliży czytelnikowi obraz stosunków Unii Europejskiej ze Stowarzyszeniem Narodów Azji Południowo-Wschodniej oraz pozwoli dostrzec główne problemy w relacjach tych organizacji.

\subsection{Rys historyczny}

Współpraca Unii Europejskiej i Stowarzyszenia Narodów Azji Południowo-Wschodniej trwa już ponad 40 lat, a wzajemne stosunki pomiędzy organizacjami rozwijają się w sferze nie tylko gospodarczej, ale także poli- 
tycznej. Pierwsze nieformalne kontakty pomiędzy Wspólnotą Europejską a ASEAN nawiązano w 1972 r. Dialog pomiędzy podmiotami został zapoczątkowany poprzez utworzenie Specjalnego Komitetu Koordynującego oraz Grupy Studyinej w celu opracowania szczegółów przyszłej współpracy. Warto wspomnieć, że Wspólnota Europejska była pierwszą organizacją, która zdecydowała się nawiązać relacje ze Stowarzyszeniem Narodów Azji Południowo-Wschodniej, a jednocześnie ASEAN został pierwszym pozaeuropejskim partnerem $\mathrm{WE}^{2}$.

Oficjalne stosunki WE-ASEAN zostały nawiązane w 1977 r., natomiast rok później zainicjowano współpracę na poziomie ministerialnym. Pierwsze Spotkanie Ministerialne odbyło się we wrześniu 1978 r. w Brukseli. Od tego czasu spotkania odbywają się regularnie co dwa lata i stanowią kluczową płaszczyznę współpracy obu ugrupowań3 ${ }^{3}$

Przełomowym momentem w stosunkach Wspólnot Europejskich ze Stowarzyszeniem Narodów Azji Południowo-Wschodniej okazał się rok 1980, kiedy podczas II Spotkania Ministerialnego podpisano Układ o Współpracy WE-ASEAN. Podpisanie tego dokumentu stanowiło początek instytucjonalizacji kontaktów oraz rozpoczęcia formalnego dialogu. W postanowieniach Układu zawarto przede wszystkim kwestie współpracy gospodarczej, handlowej i technicznej. Dodatkowo na mocy porozumienia kraje członkowskie ASEAN zostały objęte systemem powszechnych preferencji celnych (przywilej ten nie dotyczył Singapuru) ${ }^{4}$. Układ początkowo został podpisany przez WE oraz Indonezję, Malezję, Filipiny, Singapur i Tajlandię. Każde kolejne państwo członkowskie, przystępujące do Stowarzyszenia w późniejszym okresie, osobno podpisywało protokół przyłączenia do Układu. Jedynym państwem, które ostatecznie nie dołączyło do Układu o Współpracy, jest Mjanma - przyczynę stanowi tu problem demokracji oraz przestrzegania praw człowieka ${ }^{5}$.

2 A. Drzymała, Rozwój stosunków gospodarczych Unii Europejskiej z krajami Azji a współpraca na rzecz zrównoważonego rozwoju, Łódź 2016, s. 11-12. A. Pochylczuk, Unia Europejska a pozaeuropejskie instytucje integracji regionalnej, „Biuletyn Polskiego Instytutu Spraw Międzynarodowych" 2001, nr 7, s. 65-66.

3 M. Dziembała, Stosunki gospodarcze i polityczne Unii Europejskiej z krajami ASEAN na poczqtku XXI wieku, „Prace Naukowe Uniwersytetu Ekonomicznego we Wrocławiu" 2008, nr 13, Procesy integracyine w regionie Azji i Pacyfiku, s. 95; P. Kozłowski, Polityka ASEAN wobec mocarstw, [w:] Życie polityczne Azji. Realia i dążenia, J. Marszałek-Kawa (red.), Toruń 2008, s. 253.

4 A. Drzymała, op. cit., s. 12-13.

5 M. Dziembała, op. cit., s. 95-96. 
Ponowne ożywienie relacji między UE a ASEAN nastąpiło w $1994 \mathrm{r}$. po jedenastym szczycie ministerialnym, podczas którego podjęto decyzję o utworzeniu Grupy Eksperckiej (EPG). Zadaniem EPG było opracowanie wszechstronnej strategii rozwoju współpracy obu ugrupowań regionalnych we wszystkich obszarach wzajemnych relacji. Dodatkowo w tym samym roku Unia Europejska wydała dokument pt. „W kierunku nowej strategii azjatyckiej ${ }^{\prime \prime}$, w którym podkreślono znaczenie ASEAN jako kluczowego partnera UE w Azji, pomimo prowadzenia dialogu z innymi krajami azjatyckimi. Takie rozwiązanie pozwoliło na swobodne rozszerzanie powiązań Unii z innymi państwami regionu, co w konsekwencji doprowadziło do utworzenia forum dialogu Azji i Europy (ASEM) w 1996 r. w Bangkoku7.

Szczyty Azja-Europa to nieformalne spotkania przedstawicieli państw członkowskich Unii Europejskiej, Komisji Europejskiej, państw członkowskich ASEAN, Sekretariatu ASEAN, a także państw Azji Wschodniej. Spotkania te mają na celu wzmacnianie i poszerzanie współpracy pomiędzy podmiotami w sferze politycznej, gospodarczej, kulturalnej oraz intelektualnej. ASEM przybiera różne formy - od szczytów głów państw, przez spotkania ministrów spraw zagranicznych, po robocze konferencje ministerialne, w których uczestniczą odpowiednio ministrowie różnych resortów ${ }^{8}$. Trzeba również wspomnieć, że w 1995 r. doszło do pierwszego spotkania wyższych urzędników na Wyższym Szczeblu Ministerialnym ASEAN-UE w Singapurze9.

Lata 2000 przyniosły intensyfikację w kontaktach Unii Europejskiej ze Stowarzyszeniem Narodów Azji Południowo-Wschodniej - było to związane z przyjęciem unijnej strategii względem regionu Azji. W $2001 \mathrm{r}$. wydano dokument pt. „Europa i Azja: ramy strategiczne dla wzmocnionego partnerstwa10", który przede wszystkim wskazywał kluczowe znaczenie organizacji ASEAN dla dalszego pogłębiania współpracy dwóch kontynen-

6 Komisja Europejska, Towards a New Asia Strategy, Brussels, 13.07.1994, COM (94) 314 końcowy.

7 A. Pochylczuk, op. cit., s. 66.

8 M. Futyra, Stowarzyszenie Narodów Azji Południowo-Wschodniej (ASEAN) i Unia Europejska - historia współpracy, współczesne relacje, prognoza na przyszłość, www. researchgate.net/publication/268177497_Stowarzyszenie_Narodow_Azji_Poludniowo_-_Wschodniej_ASEAN_i_Unia_Europejska_-_historia_wspolpracy_wspolczesne_relacje_prognoza_na_przyszlosc (data dostępu: 6.06.2017), s. 7-8.

9 A. Drzymała, op. cit., s. 14.

10 European Commission, Europe and Asia: A strategic framework for enhanced partnerships, Brussels, 4.09.2001, COM (2001) 469 końcowy. 
tów - Europy i Azji ${ }^{11}$. Drugim wydanym dokumentem był komunikat Komisji z 2003 r. pt. „Nowe partnerstwo z Azją Południowo-Wschodniąi2”, który zapowiadał intensyfikację działań na rzecz wzmacniania wzajemnych relacji UE i ASEAN, a także z pozostałymi państwami regionu Azji Południowo-Wschodniej. Dokument ten stanowił nową strategię na rzecz rozwoju wspólpracy gospodarczej i dialogu politycznego pomiędzy tymi organizacjami. W komunikacie zapisano sześć priorytetów: 1) wspieranie regionalnej stabilności i walki z terroryzmem; 2) promowanie praw człowieka, zasad demokracji i dobrego rządzenia; 3) stawianie kwestii sprawiedliwości i spraw wewnętrznych na pierwszym planie; 4) wprowadzanie nowej dynamiki w zakresie regionalnego handlu i inwestycji; 5) dalsze wspieranie rozwoju mniej rozwiniętych państw; 6) intensyfikacja dialogu i współpraca w określonych obszarach ${ }^{13}$.

W 2003 r. weszła w życie inicjatywa TREATI (The Trans-Regional EU-ASEAN Trade Initiative), która miała za zadanie ułatwić wymianę handlową i realizację inwestycji pomiędzy Unią Europejską a państwami ASEAN. W ramach tej inicjatywy w latach 2004-2006 odbyło się łącznie jedenaście spotkań, na których omawiano współpracę w poszczególnych dziedzinach. Działania te miały na celu ukazanie pozytywnego wkładu Unii Europejskiej w wewnętrzny proces integracji Stowarzyszenia Narodów Azji Południowo-Wschodniej, a także zademonstrowanie umiejętności realnego radzenia sobie $z$ barierami w handlu pomiędzy tymi organizacjami ${ }^{14}$.

Wzmocnienie relacji UE - ASEAN na polu gospodarczym nastąpiło w 2006 r., kiedy Komisja Europejska wydała komunikat pt. „Globalna Europa: konkurując na świecie15", w którym zapowiedziała rozpoczęcie negocjacji w sprawie utworzenia strefy wolnego handlu ${ }^{16}$.

Początkowa współpraca UE - ASEAN nie była zbyt dynamiczna ze względu na wewnętrzne zmagania Europy związane $z$ upadkiem ZSRR, a także brak gotowości państw unijnych do podejmowania inicjatyw $\mathrm{w}$ tak oddalonych częściach świata ${ }^{17}$. Z czasem jednak obie organizacje

11 M. Dziembała, op. cit., s. 96.

12 European Commission, A New Partnership with South East Asia, European Commission, Brussels, 9.07.2003, COM (2003) 399 końcowy.

13 A. Drzymała, op. cit., s. 17; European Commission, op. cit.

14 A. Drzymała, op. cit., s. 17-18.

15 European Commission, Global Europe: competing in the world, Brussels, 4.10.2006, COM (2006) 567 końcowy.

16 A. Drzymała, op. cit., s. 18.

17 M. Futyra, op. cit., s. 6-7. 
zaczęły się rozwijać, a współpraca między nimi nabrała tempa. Unia Europejska otworzyła się na pogłębienie wzajemnych stosunków ze Stowarzyszeniem, co można zaobserwować, śledząc mnogość wydawanych strategii i dokumentów dotyczących współpracy w regionie Azji Południowo-Wschodniej.

\subsection{Stosunki polityczne}

Stosunki polityczne Unii Europejskiej ze Stowarzyszeniem Narodów Azji Południowo-Wschodniej funkcjonują przede wszystkim na podstawie deklaracji przyjętej na szesnastym szczycie ministrów spraw zagranicznych UE i ASEAN, który odbył się 14-15 marca 2007 r. w Norymberdze. Deklaracja ta określa długoterminową wizję i zobowiązanie obu stron do współpracy. W owym dokumencie obie organizacje po raz kolejny potwierdziły chęć zacieśniania relacji polityczno-gospodarczych oraz wspólnych działań na rzecz pokoju i dobrobytu w regionie ${ }^{18}$. Dodatkowo w deklaracji strony zobowiązały się do kooperacji w takich obszarach, jak: 1) obszar polityczny i bezpieczeństwa; 2) obszar gospodarczy; 3) obszar bezpieczeństwa energetycznego, zmian klimatycznych i środowiska; 4) obszar społeczno-kulturalny; 5) rozwój wspólnoty ASEAN19.

W roku 2008 Stowarzyszenie Narodów Azji Południowo-Wschodniej przyjęło Kartę ASEAN, która była pierwszym dokumentem nadającym osobowość prawną tej organizacji. W związku z tym Unia Europejska w marcu 2009 r. zainicjowała nawiązanie formalnych stosunków dyplomatycznych pomiędzy organizacją ASEAN a państwami członkowskimi UE. Karta ASEAN miała stać się podstawą do utworzenia Wspólnoty ASEAN w 2015 r.20

Kolejnym istotnym etapem $\mathrm{w}$ relacjach politycznych Unii Europejskiej ze Stowarzyszeniem Narodów Azji Południowo-Wschodniej było podpisanie pięcioletniego Planu Działania (Plan of Action) w Bandar Seri Begawan w kwietniu 2012 r. Była to strategia współpracy UE - ASEAN na najbliższe pięć lat, która skupiała się przede wszystkim na pogłębia-

18 ASEAN and the EU, www.eeas.europa.eu/delegations/association-southeast-asian-nations-asean/906/asean-and-eu_en (data dostępu: 6.06.2017); A. Drzymała, op. cit., s. $18-19$.

19 Nuremberg Declaration on an EU-ASEAN Enhanced Partnership, www.eeas.europa. eu/sites/eeas/files/2007_16_nuremberg_declar.pdf (data dostępu: 6.06.2017).

20 ASEAN and the EU...; J. Kisielińska, ASEAN - geneza, rozwój, powiqzania z Uniq Europejskq, Torun 2010, s. 7. 
niu i zacieśnianiu relacji w sferze polityki i bezpieczeństwa. Zapewniała ona ramy instytucjonalne do wzmocnienia dialogu politycznego pomiędzy obiema organizacjami. Plan Działania był elementem wdrażania zobowiązań zawartych w Deklaracji norymberskiej z 2007 r. ${ }^{21}$

Głównym celem owego planu było zwiększenie zaangażowania obu stron we współpracę w obszarach innych niż handel, na który kładziono największy nacisk od początku nawiązania relacji UE - ASEAN. Działania te odzwierciedlały zainteresowania obu ugrupowań w pogłębieniu kooperacji przede wszystkim w sferze politycznej. Pośród wszystkich obszarów Planu Działania z Bandar Seri Begawan wyróżniono cztery najważniejsze:

1. Promowanie regionalnej współpracy w celu utrzymania pokoju, bezpieczeństwa i stabilności w regionie; wzmocnienie pozycji ASEAN w regionie; pogłębienie dialogu politycznego i współpracy w obrębie mediacji i pojednania; współpraca w zakresie reagowania kryzysowego, bezpieczeństwa międzynarodowego i bezpieczeństwa morskiego; walka z terroryzmem i przestępczością transnarodową; łagodzenie ryzyka związanego $z$ materiałami jądrowymi; prowadzenie dialogu międzyreligijnego i w kwestii praw człowieka.

2. Współpraca gospodarcza: wsparcie dla integracji gospodarczej ASEAN; dialog na temat bezpieczeństwa żywnościowego i łączenia rynków energetycznych; wspieranie gospodarczego i społecznego dialogu pomiędzy państwami ASEAN; małe i średnie przedsiębiorstwa; wsparcie dla utworzenia jednolitego rynku lotniczego w obrębie ASEAN.

3. Współpraca społeczno-kulturalna: wsparcie dla integracji wyższej edukacji w obrębie ASEAN; wsparcie dla sieci Uniwersytetów ASEAN; system reagowania na klęski żywiołowe; zmiany klimatyczne; nauka i technologia; wsparcie dla zrównoważonego rozwoju; różnorodność biologiczna i polityka środowiskowa.

4. Wsparcie instytucjonalne dla ASEAN: wsparcie unijne dla wszystkich organów ASEAN w celu zapewnienia ich prawidłowego funkcjonowania; pomoc poprzez wymianę doświadczeń22.

21 G. Khandekar, Mapping EU-ASEAN Relations, www.fride.org/download/Mapping_ EU_ASEAN_Relations.pdf (data dostępu: 7.06.2017), s. 7-8.

22 Ibidem, s. 7-8; Bandar Seri Begawan Plan of Action to strengthen The ASEAN-EU Enhanced Partnership (2013-2017), ASEAN-EU Ministerial Meeting, Bandar Seri Begawan, Brunei, 27 April 2012; EU-ASEAN: Natural Partners, www.eeas.europa.eu/archives/docs/asean/docs/eu_asean_natural_partners_en.pdf /data dostępu: 7.06.2017), s. 1-2. 
W 2017 r. wydany został nowy Plan Działania ASEAN-UE na lata 2018-2022. De facto jest on kontynuacją poprzedniego planu $z$ bardzo podobnymi założeniami i obszarami pogłębiania współpracy, prowadzącymi do ugruntowania „wzmocnionego partnerstwa” obu stron. Podobnie jak w przypadku poprzedniego planu działania, w nowym dokumencie wyróżnić można cztery najważniejsze obszary kooperacji: 1) współpracę polityczną i w kwestii bezpieczeństwa; 2) współpracę gospodarczą; 3) współpracę społeczno-kulturalną; 4) współpracę w kwestii łączności wewnątrzregionalnej. Najważniejszym wyzwaniem zawartym w Planie Działania na lata 2018-2022 jest inicjatywa pogłębiania integracji wewnątrz Stowarzyszenia Narodów Azji Południowo-Wschodniej oraz zmniejszenia różnic rozwojowych pomiędzy państwami członkowskimi tej organizacji23.

W 2012 r. Unia Europejska przystąpiła do Traktatu o przyjaźni i współpracy w Azji Południowo-Wschodniej, który jest traktatem pokojowym państw regionu, ustanowionym przez członków założycieli ASEAN. Był to istotny krok w stronę zwiększenia zaangażowania politycznego i dotyczącego spraw bezpieczeństwa Unii w regionie. 8 sierpnia 2015 r. Unia Europejska ustanowiła misję dyplomatyczną przy organizacji ASEAN i mianowała dedykowanego ambasadora. Obecnie akredytowanych jest 25 ambasadorów z państw UE przy Stowarzyszeniu 24.

Swoją obecność w regionie Unia Europejska zaznacza również poprzez uczestnictwo w Regionalnym Forum ASEAN, które stanowi formę wielostronnego i zinstytucjonalizowanego dialogu w obszarze pokoju i bezpieczeństwa, prowadzonego przez ASEAN. Dodatkowo UE jest członkiem ASEM, w ramach którego prowadzony jest międzyregionalny dialog Azja - Europa ${ }^{25}$.

UE i ASEAN współpracowały również w wielu nietradycyjnych obszarach bezpieczeństwa, takich jak: bezpieczeństwo morskie, zapobieganie konfliktom, mediacja i pojednanie, zarządzanie kryzysowe, przestępczość transgraniczna, przeciwdziałanie terroryzmowi, cyberbezpieczeństwo oraz nierozprzestrzenianie broni jądrowej ${ }^{26}$.

23 ASEAN-EU Plan of Action (2018-2022), ASEAN-EU Ministerial Meeting, Manila, Philippines, 6 August 2017.

24 The EU Accedes to Treaty of Amity and Cooperation in Southeast Asia, www.europa.eu/ rapid/press-release_IP-12-781_en.htm (data dostępu: 7.06.2017); ASEAN and the EU...

25 M. Dziembała, op. cit., s. 97.

26 ASEAN and the EU..., op. cit. 
Najnowszym dokumentem przedstawiającym priorytetowe dziedziny współpracy pomiędzy Unią Europejską a Stowarzyszeniem Narodów Azji Południowo-Wschodniej jest „UE i ASEAN: partnerstwo o strategicznym celu27". Dokument ten został wydany w 2015 r. i wyznacza siedem obecnie najważniejszych celów i obszarów, w których organizacje te powinny podjąć współpracę, takich jak:

1) pogłębianie integracji pomiędzy państwami ASEAN, a także wzmacnianie powiązań organizacji z resztą świata;

2) pobudzanie wzrostu wymiany handlowej i inwestycji oraz stwarzanie odpowiedniego środowiska dla zaangażowania europejskich przedsiębiorstw;

3) wspieranie rozwoju transportu, zwłaszcza inicjatywy wspólnego rynku lotnictwa cywilnego ASEAN;

4) współpraca w dziedzinie rozwoju badań, innowacji i kontaktów międzyludzkich, w tym także wymiany studenckiej;

5) zwiększanie efektywności dialogu dotyczącego zmian klimatycznych i ochrony środowiska w regionie;

6) rozwój współpracy w obszarze polityki i bezpieczeństwa, w celu wykształcenia bardziej zrównoważonego partnerstwa, wykraczającego poza tradycyiny nacisk na kwestie gospodarcze;

7) promowanie i ochrona praw człowieka, szczególnie w odniesieniu do kary śmierci, sytuacji mniejszości oraz praw kobiet.

Najważniejszym priorytetem Unii Europejskiej zawartym w strategii jest jednak przekształcenie obecnego „naturalnego i wzmocnionego" partnerstwa pomiędzy UE i ASEAN w partnerstwo strategiczne28.

Pomimo podejmowania wielu starań na rzecz pogłębienia kontaktów politycznych, a także budowania nowych płaszczyzn umożliwiających współpracę, kooperacja polityczna między Unią Europejską a Stowarzyszeniem Narodów Azji Południowo-Wschodniej ma wciąż relatywnie niewielkie znaczenie. Od roku 1996 systematycznie wzrastało znaczenie ASEM jako głównej płaszczyzny, na której toczy się dialog UE - Azja, co postawiło na drugim miejscu współpracę instytucjonalną pomiędzy UE i ASEAN. Źródłem problemu nieefektywnej kooperacji instytucjonalnej są różnice w podejściu obu organizacji do ponadregionalnej współpracy. Unia Europejska od zawsze stawiała na silną instytucjonalizację kontaktów, natomiast

27 European Commission, The EU and ASEAN: a partnership with a strategic purpose, Brussels, 18.05.2015, JOIN (2015) 22 końcowy.

28 Ibidem. 
ASEAN stworzył swój własny sposób działania, opierający się na konsensusie, nieformalnych konsultacjach i niskim poziomie instytucjonalizacji. ASEAN Way stosowana jest także w kontaktach ponadregionalnych, w tym z Unią Europejską. Jednakże pomimo wielu problemów relacje polityczne UE - ASEAN nie zostały porzucone i na przestrzeni lat nastąpił zauważalny rozwój współpracy instytucjonalnej pomiędzy tymi organizacjami. Nadanie osobowości prawnej ASEAN, a także dążenie do utworzenia Wspólnoty ASEAN, inspirowanej strukturą Unii Europejskiej, przybliżają obie organizacje i dają szansę na poszerzenie kontaktów politycznych ${ }^{29}$.

Kolejny dylemat stanowi kwestia łamania praw człowieka w państwach ASEAN. Organizacja ta podjęła szereg działań na rzecz ochrony praw człowieka oraz w obszarze demokracji, co wpłynęło na poprawę relacji z Unią Europejską i w pewnym stopniu pozwoliło usunąć bariery w międzyregionalnej współpracy. Pomimo podjętych działań problem ten wciąż jest obecny. Co więcej, walka z terroryzmem w regionie po $2001 \mathrm{r}$. zachęciła niektóre państwa Azji Południowo-Wschodniej do podjęcia na nowo pod pretekstem tejże walki zmilitaryzowanych i nieprzejrzystych działań, które nie mają wiele wspólnego z polityką ochrony praw człowieka. Łamanie praw człowieka jest częstym zjawiskiem w państwach azjatyckich, a zlikwidowanie tego problemu będzie wymagało dużego zaangażowania i czasu ${ }^{30}$.

Relacje polityczne Unii Europejskiej i Stowarzyszenia Narodów Azji Południowo-Wschodniej nie są tak rozwinięte jak relacje gospodarcze. Od momentu nawiązania stosunków politycznych strony stawiały nacisk przede wszystkim na współpracę ekonomiczną i handel, ponieważ był to obszar, na którym najbardziej zależało państwom rozwijającym się, wchodzącym w skład Stowarzyszenia. Dodatkowo w relacjach UE - ASEAN występują pewne problemy związane $z$ nieefektywną współpracą instytucjonalną, a także dotyczące kwestii łamania praw człowieka w regionie. Obie strony wykazują natomiast coraz większe zaangażowanie w proces rozwiązywania występujących problemów oraz rozwijania współpracy i dialogu w sferze polityki i bezpieczeństwa, w celu wykształcenia strategicznego partnerstwa, które ma wykraczać poza tradycyjny nacisk na kwestie gospodarcze.

29 M.B. Manea, The Institutional Dimension of EU-ASEAN/ASEAN Plus Three Inter-regional Relations, [w:] The Palgrave Handbook of EU-Asia Relations, T. Christiansen, E. Kirchner i P. Murray (eds.), London 2015, s. 113-327.

30 Ibidem, s. 323-326. 


\subsection{Stosunki gospodarcze}

Współpraca gospodarcza i handel to jeden z najistotniejszych aspektów stosunków Unii Europejskiej ze Stowarzyszeniem Narodów Azji Południowo-Wschodniej. Wymiana handlowa UE - ASEAN w 2017 r. stanowiła $6,1 \%$ (z czego $7,3 \%$ to import, a 4,9\% - eksport) łącznej wartości wszystkich transakcji handlowych Unii. Unia Europejska jest bardzo ważnym rynkiem zbytu dla produktów pochodzących z państw członkowskich ASEAN i z tego względu jest drugim największym partnerem handlowym Stowarzyszenia, zaraz po Chinach. Z kolei ASEAN jest dla Unii trzecim największym partnerem handlowym spoza Europy, zaraz po USA i Chinach. Dodatkowo UE jest największym inwestorem w krajach ASEAN. Całkowita wartość unijnych bezpośrednich inwestycji zagranicznych w 2016 r. wyniosła 234 mld euro, czyli prawie 1/4 całości inwestycji w tym regionie. Od 2004 r. przedsiębiorstwa z Unii Europejskiej inwestują średnio 15 mld euro rocznie w regionie. Problemem jest jedynie fakt, że większość inwestycji europejskich skupiona jest na Singapurze ${ }^{31}$.

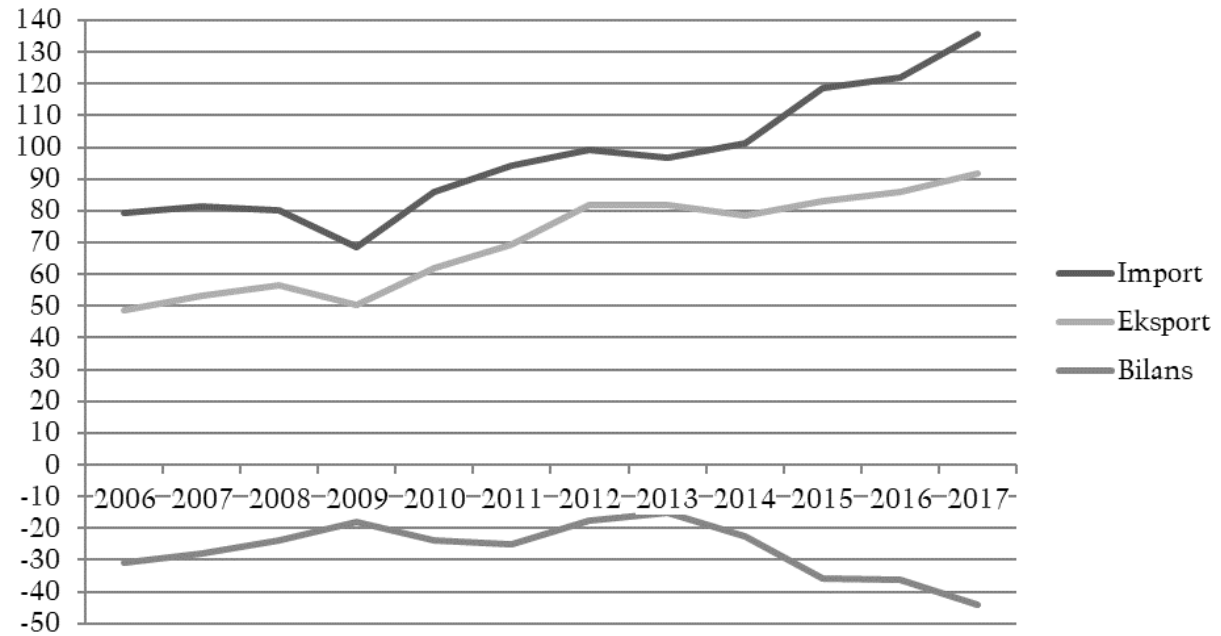

Wykres 9. Przepływ towarów i bilans handlowy UE (mln euro) w latach 2006-2017

Źródło: European Commission, Directorate General for Trade, European Union, Trade in goods with ASEAN (Association of South-East Asian Nations), 16.04.2018, s. 3.

31 European Commission, Directorate General for Trade, European Union, Trade in goods with ASEAN (Association Of South-East Asian Nations), 16.04.2018, s. 1; M. Dziembała, op. cit., s. 98; European Commission and ASEAN, Blue Book 2017. EU-ASEAN Development Cooperation in 2016. 40 Years of Partnership and Cooperation, 5.08.2017, s. 20. 
Wartość wymiany handlowej UE z ASEAN systematycznie wzrasta, co można zaobserwować (wykres 9). Po spadku w 2009 r., który nastąpił ze względu na globalny kryzys finansowy, handel z krajami Stowarzyszenia wzrósł na nowo, począwszy od roku 2010. Co więcej, przez ostatnią dekadę import UE z ASEANU wzrósł o ponad 40\%, a eksport o ponad 80\%32. W 2017 r. łączna wartość wymiany handlowej wyniosła prawie $228 \mathrm{mln}$ euro, w tym ponad $135 \mathrm{mln}$ z importu i ponad $91 \mathrm{mln} z$ eksportu, osiągając tym samym najwyższą odnotowaną wartość wymiany od nawiązania stosunków gospodarczych między tymi ugrupowaniami. Unia Europejska odnotowuje ujemny bilans handlowy w wymianie towarowej z państwami ASEAN, który w roku 2017 wyniósł 44 mln euro33.

Głównymi produktami eksportowanymi z Unii Europejskiej są maszyny, urządzenia transportowe, produkty chemiczne oraz metale nieszlachetne. Natomiast ASEAN eksportuje do UE przede wszystkim tkaniny i odzież, chemikalia, sprzęt i urządzenia elektroniczne oraz towary konsumpcyjne. Należy zauważyć, że po stronie zarówno importu, jak i eksportu dominują produkty przemysłowe ${ }^{34}$.

Przyglądając się wymianie handlowej UE z poszczególnymi krajami ASEAN, widzimy, że Unia najwięcej eksportuje do Singapuru - import jest tam o połowę mniejszy, dlatego bilans handlowy jest dodatni (wykres 10). Natomiast największy import występuje w wymianie handlowej z Wietnamem - eksport do tego państwa jest znacznie mniejszy, dlatego bilans handlowy jest ujemny. Największą wymianę handlową Unia Europejska prowadzi z pięcioma krajami ASEAN: Singapurem, Malezją, Tajlandią, Wietnamem i Indonezją. Do tej listy można ewentualnie dodać także Filipiny, ale wymiana handlowa $z$ tym państwem jest już znacznie mniejsza. Handel z pozostałymi czterema krajami członkowskimi ASEAN odgrywa natomiast mało istotną rolę35.

W 2007 r. Komisja Europejska została oficjalnie upoważniona przez Radę UE do rozpoczęcia negocjacji w sprawie utworzenia strefy wolnego handlu. Pierwsze rozmowy na temat FTA (Free Trade Agreements) podjęto podczas szczytu ministrów resortów ekonomicznych w Brunei w maju

32 ASEAN and the EU...

33 EU-ASEAN Cooperation - key trade and investment statistics, www.ec.europa.eu/ eurostat/statistics-explained/index.php/EU-ASEAN_cooperation_-_key_trade_and_ investment_statistics (data dostępu: 21.07.2018); European Union, Trade in goods with ASEA $\bar{N}$..., s. 1-3.

34 EU-ASEAN Cooperation...

35 Ibidem. 
2007 r. Proces negocjacji między Unią Europejską a ASEAN miał być dostosowany do zróżnicowanego poziomu rozwoju poszczególnych państw członkowskich ASEAN. Zawarcie umowy o wolnym handlu pozwoliłoby na poszerzenie współpracy pomiędzy tymi organizacjami i wpłynęłoby pozytywnie na proces liberalizacji handlu oraz przepływu inwestycji. Skutkiem podpisania FTA byłoby także zwiększenie zatrudnienia i przyspieszenie wzrostu gospodarczego w regionie. Jednakże duże zróżnicowanie krajów członkowskich Stowarzyszenia, pod względem zarówno politycznym, jak i ekonomicznym, uniemożliwia wypracowanie jednej oferty negocjacyjnej dla wszystkich państw ASEAN36.

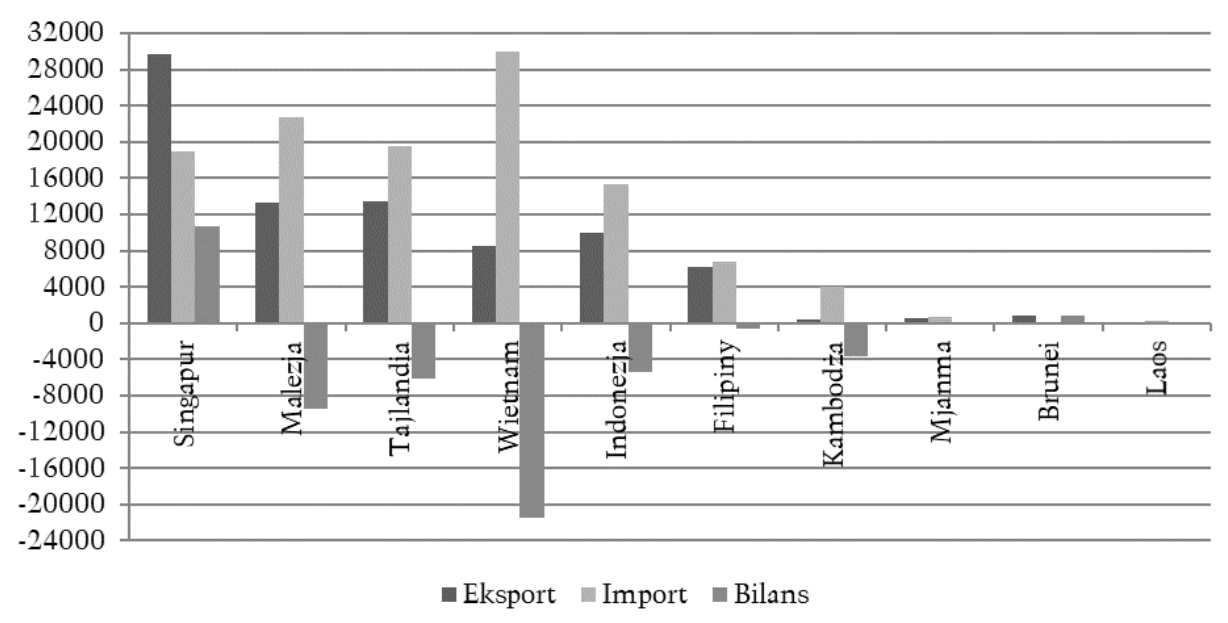

Wykres 10. Eksport i import UE z poszczególnymi państwami ASEAN w 2015 r. (w mln euro)

Źródło: EU-ASEAN cooperation - key trade and investment statistics, www.ec.europa. eu/eurostat/statistics-explained/index.php/EU-ASEAN_cooperation_-_key_trade_and_investment_statistics (data dostępu: 21.07.2018).

W 2009 r. negocjacje w sprawie utworzenia strefy wolnego handlu zostały tymczasowo zawieszone ze względu na różnice polityczne i ekonomiczne wewnątrz Stowarzyszenia. Państwa członkowskie ASEAN po prostu nie były w stanie wypracować wspólnego stanowiska w rokowaniach.

36 C. Alvstam, L. Lindberg, EU-ASEAN Trade Facing Free Trade Negotiations, 10th Annual Conference on European Integration, The Swedish Network for European Studies in Economics and Business (SNEE), Mölle, Sweden, 20-23 May 2008, s. 6-7; S. Kabir, R. Salim, Parallel Integration and ASEAN-EU Trade Potential: an Empirical Analysis, „Journal of Economic Integration” 2011, vol. 26, issue 4, s. 604-607. 
Z czasem strony zdecydowały się na zawieranie bilateralnych umów handlowych UE z państwami Stowarzyszenia ${ }^{37}$.

Tabela 6. Państwa członkowskie ASEAN a FTA

\begin{tabular}{|l|l|l|}
\hline \multicolumn{3}{|c|}{ Państwa członkowskie ASEAN a umowa o wolnym handlu (FTA) } \\
\hline \multicolumn{1}{|c|}{ Podpisana umowa } & \multicolumn{1}{|c|}{ Negocjacje } & \multicolumn{1}{c|}{ Brak umowy } \\
\hline 1. Singapur & 3. Malezja & 7. Mjanma \\
2. Wietnam & 4. Tajlandia & 8. Laos \\
& 5. Filipiny & 9. Kambodża \\
& 6. Indonezja & 10. Brunei \\
\hline
\end{tabular}

Źródło: ASEAN and the EU, www. eeas.europa.eu/delegations/association-southeast-asian-nations-asean/906/asean-and-eu_en (data dostępu: 6.06.2017).

Ostatecznie umowy o wolnym handlu zostały podpisane $\mathrm{z}$ dwoma krajami: Singapurem w 2013 r. i Wietnamem w 2015 r. Negocjacje umów o wolnym handlu zostały także rozpoczęte z Malezją w 2010 r., z Tajlandią w 2013 r., a także z Filipinami w 2015 r. Rozpoczęcie negocjacji z Indonezją ogłoszono stosunkowo niedawno, w 2016 r. ${ }^{38}$

Pozostałe państwa członkowskie ASEAN nie rozpoczęły jeszcze żadnych negocjacji w sprawie zawarcia FTA, natomiast uczestniczą w innych inicjatywach ekonomicznych i gospodarczych UE. Dla przykładu: w Mjanmie od 2014 r. działa umowa o ochronie inwestycji, a od 2016 r. trwa dyskusja na temat wprowadzenia umowy o partnerstwie gospodarczym z Indonezją (umowa ta ma na celu stopniowo zastępować system handlu preferencyjnego UE). Kambodża i Laos są z kolei objęte programem „Wszystko oprócz broni", dzięki czemu mają preferencyjny dostęp do rynku europejskiego, za wyjątkiem eksportu broni i uzbrojenia ${ }^{39}$.

Wartość wymiany handlowej Unii Europejskiej ze Stowarzyszeniem Narodów Azji Południowo-Wschodniej systematycznie wzrasta od lat. UE zwiększa swoją obecność i zaangażowanie w Azji Południowo-Wschodniej ze względu na dynamiczny wzrost znaczenia gospodarczego państw regionu oraz postępujący proces integracji i liberalizacji handlu. Jedynym problemem w kontaktach gospodarczych UE - ASEAN z punktu widzenia państw członkowskich Stowarzyszenia jest brak jednej umowy o wolnym handlu dla całej organizacji. Taka sytuacja powoduje, że część państw

37 A. Drzymała, op. cit., s. 19.

38 A. Amighini, EU External Trade Strategy vis-à-vis Asia, www.ispionline.it/sites/default/files/pubblicazioni/eu_asia_2., 7.03.2016, s. 26-27.

39 ASEAN and the EU..., op. cit. 
traktowana jest bardziej partnersko, a część pozostaje na drugim planie. Możliwość podpisywania umów bilateralnych sprzyja natomiast interesom Unii Europejskiej. Jako duży partner jest ona w stanie wynegocjować dla siebie korzystniejsze zapisy z poszczególnymi małymi krajami niż w przypadku negocjacji z całą organizacją ASEAN.

\subsection{Pomoc rozwojowa}

Unia Europejska angażuje się w regionie Azji Południowo-Wschodniej także poprzez udzielanie pomocy rozwojowej i humanitarnej. Istnieje wiele programów, w ramach których dostarcza ona pomoc potrzebującym państwom. Programy te obejmują bardzo różnorodne obszary, np. ochronę środowiska, walkę z ubóstwem, edukację czy chociażby wsparcie dla integracji ekonomicznej krajów ASEAN40.

Obecną strategią Unii Europejskiej względem Stowarzyszenia Narodów Azji Południowo-Wschodniej jest „Współpraca EU - ASEAN 2014-2020". Strategia ta została przyjęta w styczniu 2014 r. w Dżakarcie podczas 21. Spotkania Wspólnego Komitetu Współpracy ASEAN-UE (JCC). W ramach tego programu Unia ma przeznaczyć prawie $200 \mathrm{mln}$ euro na realizację wszystkich celów, czyli prawie trzy razy więcej niż w poprzedniej strategii na lata 2007-2013. Dodatkowo UE przeznaczyła prawie 3 mld euro na cele redukcji biedy w regionie i pomoc dla biedniejszych państw ASEAN. Unia Europejska udziela też pomocy rozwojowej państwom członkowskim ASEAN w ramach współpracy bilateralnej (wykres 11)41.

Strategia „Współpraca EU - ASEAN” podzielona jest na trzy ogniskowe sektory: 1) zrównoważony rozwój, integracja gospodarcza i handel; 2) zmiany klimatyczne, środowisko i zarządzanie kryzysowe; 3) kompleksowy dialog 42 .

Celem pierwszego sektora strategii jest rozwój współpracy państw członkowskich ASEAN poprzez gospodarczą integrację i handel, ze szczególnym skupieniem się na państwach takich jak Kambodża, Laos, Mjanma i Wietnam ${ }^{43}$.

40 Ibidem.

41 EU-ASEAN Cooperation and Development, www.webgate.ec.europa.eu/fpfis/mwikis/ aidco/images/e/ec/2_EU-ASEAN.pdf (data dostępu: 22.04.2017).

42 ASEAN and the EU..., op. cit.

43 EU-ASEAN Cooperation..., op. cit. 
$128 \vdots$ Angelika Korczyńska

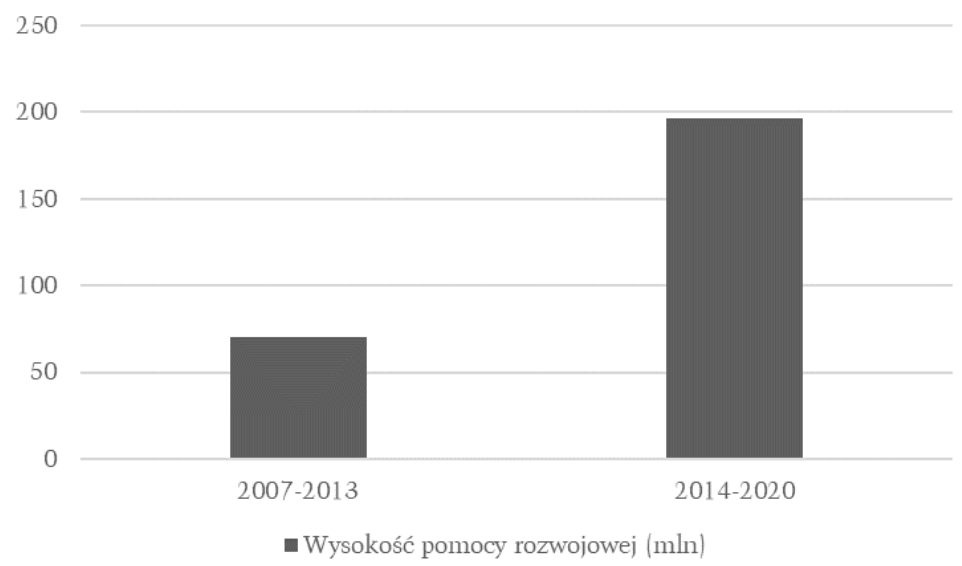

Wykres 11. Pomoc rozwojowa UE dla krajów ASEAN (w mln euro)

Źródło: EU-ASEAN Cooperation and Development, www.webgate.ec.europa.eu/fpfis/ mwikis/aidco/images/e/ec/2_EU-ASEAN.pdf (data dostępu: 7.06.2017).

W obszarze zmian klimatycznych priorytetem jest: 1) zrównoważone wykorzystanie torfowisk i ograniczanie problemów spowodowanych smogiem; 2) program przyjaznych dla środowiska, niskoemisyjnych i odpornych na zmianę klimatu miast; 3) edukacja ekologiczna. Dodatkowo nacisk położono również na ochronę bioróżnorodności i zarządzanie obszarami chronionymi, a także na wzmocnienie systemów zarządzania kryzysowego ${ }^{44}$.

W ostatnim sektorze strategii - kompleksowym dialogu - najistotniejszy jest program E-READI, który ma za zadanie pomóc zwiększyć integrację regionalną i zmniejszyć ubóstwo w obrębie państw ASEAN. E-READI oferuje pomoc techniczną i dialog z UE w wielu sektorach, takich jak:

1. prawa człowieka, współpraca morska, pokój i pojednanie, obserwacja wyborów, migracja i mobilność w filarze bezpieczeństwa i polityce;

2. nauka i technologia, ICT, energia, handel, rolnictwo i zasoby naturalne, leśnictwo w filarze gospodarczym ${ }^{45}$.

Oprócz typowej pomocy rozwojowej w regionie Azji Południowo-Wschodniej Unia Europejska dostarcza również pomoc w mniej tradycyjnych obszarach. Jest np. głównym donatorem procesu pokojowego w Mindanao, gdzie trwa konflikt ze społecznością muzułmańską zamiesz-

44 Ibidem.

45 Ibidem. 
kującą Filipiny. Dodatkowo UE przeznacza również środki na pomoc humanitarną, z czego w 2013 r. przekazała $40 \mathrm{mln}$ euro na wsparcie dla osób, które ucierpiały podczas tajfunu Haiyan na Filipinach ${ }^{46}$.

\section{Konkluzje}

Stowarzyszenie Narodów Azji Południowo-Wschodniej jest prężnie rozwijającą się siłą polityczną na terytorium azjatyckim. Organizacja ta przeżywa dynamiczny rozwój gospodarczy, a także odgrywa coraz istotniejszą rolę na arenie międzynarodowej. Coraz więcej podmiotów międzynarodowych dostrzega postępującą integrację państw Azji Południowo-Wschodniej, dzięki czemu wzrasta zainteresowanie rozwojem współpracy z tym ugrupowaniem.

UE zainteresowała się wspólpracą z ASEAN ze względu na powiązania historyczne, polityczne i gospodarcze z państwami członkowskimi, ale także dlatego, że dostrzegła potencjał tej rozwijającej się organizacji, notabene stworzonej na podobieństwo Unii Europejskiej. Niestety w relacjach UE - ASEAN występują pewne problemy polityczne. Jednym z nich jest niewielka konsolidacja polityczna, w stosunku do bardzo rozwiniętej współpracy gospodarczej. Wynika to z faktu, że od początku państwa członkowskie Stowarzyszenia zainteresowane były przede wszystkim współpracą ekonomiczną, ze względu na chęć poprawy stanu własnej gospodarki. Dodatkowym utrudnieniem jest postrzeganie ASEAN przez UE jako jeszcze nierozwiniętego, potrzebującego wciąż pomocy i niewystarczająco wiarygodnego partnera do prowadzenia poważniejszych relacji politycznych.

Kolejny dylemat wiąże się z tym, że pomimo wielu starań relacje polityczne pomiędzy Unią Europejską a Stowarzyszeniem Narodów Azji Południowo-Wschodniej wciąż zachowują relatywnie marginalne znaczenie. Źródła tego można upatrywać w nieefektywnej kooperacji instytucjonalnej, która wynika z odmiennych podejść obu organizacji do prowadzenia ponadregionalnej współpracy. UE od zawsze bowiem stawiała na instytucjonalizację kontaktów, natomiast ASEAN wypracował nieco bardziej nieformalny sposób prowadzenia działań politycznych.

46 K. Brutas, Top Development Aid Donors to the Philippines 2015, www.devex.com/ news/top-development-aid-donors-to-the-philippines-2015-89091 (data dostępu: 7.06.2017). 
Bardzo istotna jest również kwestia łamania praw człowieka, która bezpośrednio wpływa na relacje UE - ASEAN, a także stwarza pewne bariery w międzyregionalnej współpracy. Pomimo podjęcia przez Stowarzyszenie pewnych działań na rzecz poprawy ochrony praw człowieka problem ten jest wciąż obecny w regionie Azji Południowo-Wschodniej, a zlikwidowanie go będzie wymagało dużo zaangażowania i czasu.

Politycy unijni wciąż podejmują nowe inicjatywy polityczne względem ASEAN. Prowadzony jest dialog polityczny, rozwijana jest współpraca gospodarcza oraz wydawane są nowe dokumenty, deklaracje i strategie na rzecz pogłębienia obustronnych stosunków. UE coraz częściej podejmuje działania na rzecz rozwoju nie tylko współpracy ekonomicznej, ale także dialogu politycznego i dotyczącego spraw bezpieczeństwa. Dodatkowo Unia Europejska udziela państwom członkowskim ASEAN pomocy rozwojowej w najróżniejszych obszarach.

Zamierza ona utrzymać swoją pozycję w regionie Azji Południowo-Wschodniej, o czym świadczą liczne podejmowane inicjatywy. Politycy unijni mają świadomość postępujących procesów integracyjnych, liberalizacji handlu oraz wzrostu znaczenia gospodarczego tej części świata, jednak konieczne jest, aby Unia Europejska zaczęła traktować Stowarzyszenie Narodów Azji Południowo-Wschodniej jako równego partnera w dialogu politycznym.

\section{Bibliografia}

Alvstam C., Lindberg L., EU-ASEAN trade facing free trade negotiations, 10th Annual Conference on European Integration, The Swedish Network for European Studies in Economics and Business (SNEE), Mölle, Sweden, 20-23 May 2008.

Amighini A., EU External Trade Strategy vis-à-vis Asia, www.ispionline.it/sites/default/ files/pubblicazioni/eu_asia_2 (data dostępu: 7.03.2016), s. 26-27.

ASEAN and the EU, www.eeas.europa.eu/delegations/association-southeast-asian-nations-asean/906/asean-and-eu_en (data dostępu: 6.06.2017).

ASEAN-EU Plan of Action (2018-2022), ASEAN-EU Ministerial Meeting, Manila, Philippines, 6 August 2017.

Bandar Seri Begawan Plan of Action to strengthen The ASEAN-EU Enhanced Partnership (2013-2017), ASEAN-EU Ministerial Meeting, Bandar Seri Begawan, Brunei, 27 April 2012.

Brutas K., Top Development Aid Donors to the Philippines 2015, www.devex.com/news/top-development-aid-donors-to-the-philippines-2015-89091 (data dostępu: 7.06.2017).

Drzymała A., Rozwój stosunków gospodarczych Unii Europejskiej z krajami Azji a współpraca na rzecz zrównoważonego rozwoju, Łódź 2016.

Dziembała M., Stosunki gospodarcze i polityczne Unii Europejskiej z krajami ASEAN na poczqtku XXI wieku, „Prace Naukowe Uniwersytetu Ekonomicznego we Wrocławiu” 2008, nr 13, Procesy integracyine w regionie Azji i Pacyfiku. 
The EU Accedes to Treaty of Amity and Cooperation in Southeast Asia, www.europa.eu/ rapid/press-release_IP-12-781_en.htm (data dostępu: 7.06.2017).

EU-ASEAN Cooperation - key trade and investment statistics, www.ec.europa.eu/eurostat/statistics-explained/index.php/EU-ASEAN_cooperation_-_key_trade_and_investment_statistics (data dostępu: 21.07.2018).

EU-ASEAN Cooperation and Development, www.webgate.ec.europa.eu/fpfis/mwikis/aidco/images/e/ec/2_EU-ASEAN.pdf (data dostępu: 22.04.2017).

EU-ASEAN: Natural Partners, www.eeas.europa.eu/archives/docs/asean/docs/eu_asean_natural_partners_en.pdf (data dostępu: 7.06.2017).

European Commission and ASEAN, Blue Book 2017. EU-ASEAN Development Cooperation in 2016. 40 Years of Partnership and Cooperation, 5.08.2017.

European Commission, A new partnership with South East Asia, Brussels, 9.07.2003, COM (2003) 399 końcowy.

European Commission, Directorate General for Trade, European Union, Trade in goods with ASEAN (Association Of South-East Asian Nations), 16.04.2018.

European Commission, Europe and Asia: A strategic framework for enhanced partnerships, Brussels, 4.09.2001, COM (2001) 469 końcowy.

European Commission, Global Europe: competing in the world, Brussels, 4.10.2006, COM (2006) 567 końcowy.

European Commission, The EU and ASEAN: a partnership with a strategic purpose, Brussels, 18.05.2015, JOIN (2015) 22 końcowy.

European Commission, Towards a New Asia Strategy, Brussels, 13.07.1994, COM (94) 314 końcowy.

Fijałkowski Ł., Polus A., Azja Południowo-Wschodnia i Australazja w stosunkach międzynarodowych, Wrocław 2006.

Futyra M., Stowarzyszenie Narodów Azji Południowo-Wschodniej (ASEAN) i Unia Europejska - historia współpracy, współczesne relacje, prognoza na przyszłość, www. researchgate.net/publication/268177497_Stowarzyszenie_Narodow_Azji_Poludniowo_-_Wschodniej_ASEAN_i_Unia_Europejska_-_historia_wspolpracy_wspolczesne_ relacje_prognoza_na_przyszlosc (data dostępu: 6.06 .2017 ).

Grabowski M., Rywalizacja czy integracja? Procesy i organizacje integracyjne w regionie Azji i Pacyfiku na przełomie XX i XXI wieku, Kraków 2015.

Kabir S., Salim R., Parallel Integration and ASEAN-EU Trade Potential: an Empirical Analysis, „Journal of Economic Integration” 2011, vol. 26, issue 4.

Khandekar G., Mapping EU-ASEAN Relations, www.fride.org/download/Mapping_EU_ ASEAN_Relations.pdf (data dostępu: 7.06.2017).

Kisielińska J., ASEAN - geneza, rozwój, powiqzania z Uniq Europejskq, Uniwersytet im. Mikołaja Kopernika w Toruniu, Toruń 2010.

Kozłowski P., Polityka ASEAN wobec mocarstw, [w:] Życie polityczne Azji. Realia i dą̇enia, J. Marszałek-Kawa (red.), Toruń 2008.

Manea M.G., The Institutional Dimension of EU-ASEAN/ASEAN Plus Three Inter-regional Relations, [w:] The Palgrave Handbook of EU-Asia Relations, T. Christiansen, E. Kirchner, P. Murray (eds.), London 2015.

Nuremberg Declaration on an EU-ASEAN Enhanced Partnership, www.eeas.europa.eu/sites/eeas/files/2007_16_nuremberg_declar.pdf (data dostępu: 6.06.2017).

Pochylczuk A., Unia Eüropejska a pozaeuropejskie instytucje integracji regionalnej, „Biuletyn Polskiego Instytutu Spraw Międzynarodowych" 2001, nr 7. 